\title{
Characterization of New Ent-kaurane Diterpenoids of Yunnan Arabica Coffee Beans
}

\author{
Rui Chu $\cdot$ Luo-Sheng Wan $\cdot$ Xing-Rong Peng $\cdot$ \\ Mu-Yuan Yu $\cdot$ Zhi-Run Zhang $\cdot$ Lin Zhou • \\ Zhong-Rong Li $\cdot$ Ming-Hua Qiu
}

Received: 22 March 2016/Accepted: 10 April 2016/Published online: 10 May 2016

(C) The Author(s) 2016. This article is published with open access at Springerlink.com

\begin{abstract}
Five new ent-kaurane diterpenoids, named mascaroside III-V (1-3), and 20-nor-cofaryloside I-II (4-5), together with seven known diterpenoids, were isolated from methanol extracts of the green coffee beans of Yunnan Arabica Coffee. Their chemical structures were elucidated by extensive spectroscopic analyses. Meanwhile, cytotoxicity assay against HL60, A-549, SMMC-7721, MCF-7 and SW480 cell lines showed that they have not evident inhibition of cytotoxicity.
\end{abstract}
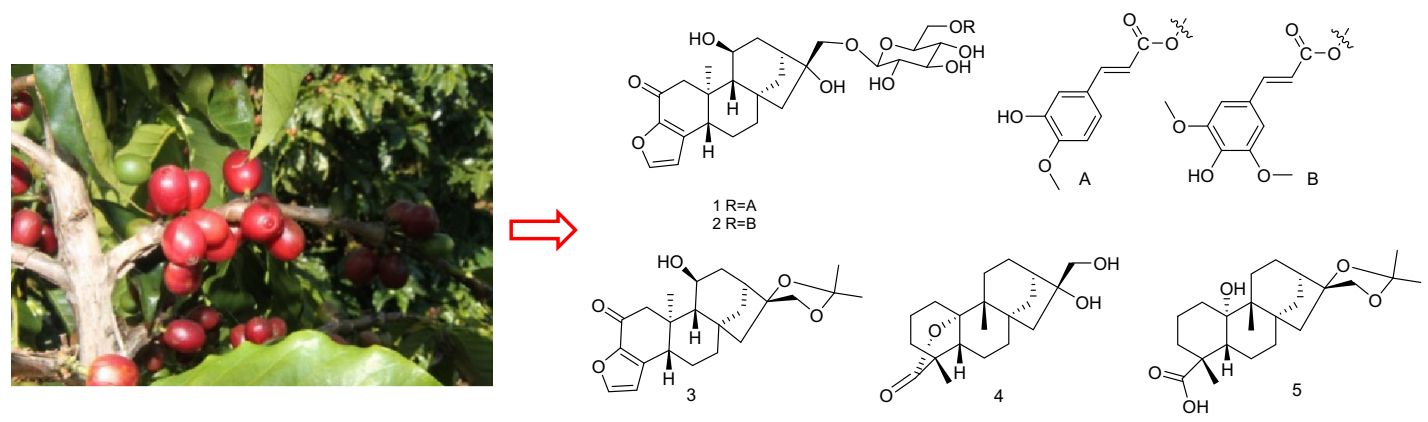

Keywords Coffea arabica L. · Green coffee beans · Diterpenoids · Structural elucidation

Electronic supplementary material The online version of this article (doi:10.1007/s13659-016-0099-1) contains supplementary material, which is available to authorized users.

R. Chu $\cdot$ L.-S. Wan $\cdot$ X.-R. Peng $\cdot$ M.-Y. Yu $\cdot$ Z.-R. Zhang $\cdot$ L. Zhou - Z.-R. Li · M.-H. Qiu ( $₫)$

State Key Laboratory of Phytochemistry and Plant Resources in West China, Kunming Institute of Botany, Chinese Academy of Sciences, Kunming 650201, China

e-mail: mhchiu@mail.kib.ac.cn

R. Chu · M.-Y. Yu · M.-H. Qiu

University of Chinese Academy of Sciences, Beijing 100049, China

\section{Introduction}

Coffea arabica L., commonly known as coffee and widely distributed throughout the world, involving Africa, Latin America and Asia, is a very popular hot drink around the world because of its attractive aroma and unique taste [1, 2]. Previous studies have shown that coffee beans are consisted of caffeine, chlorogenic acids, saccharides [3-5], as well as diterpenoids, although, taking a minor proportion in the chemical constituents of coffee. However, due to their broad spectrum of biological activities, such as cytotoxicity, antioxidant, anti-inflammatory, researchers have carried out work on diterpenoids components from 


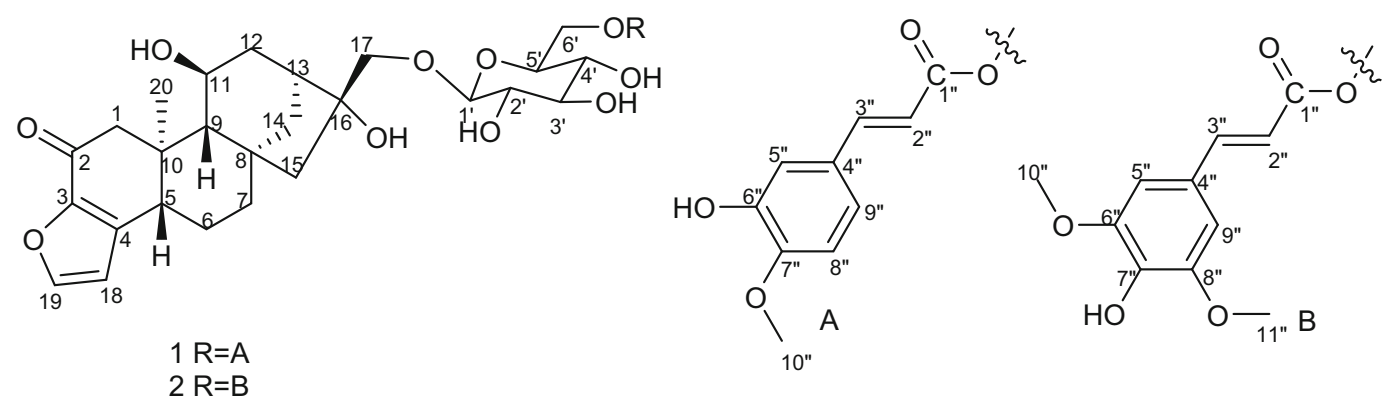

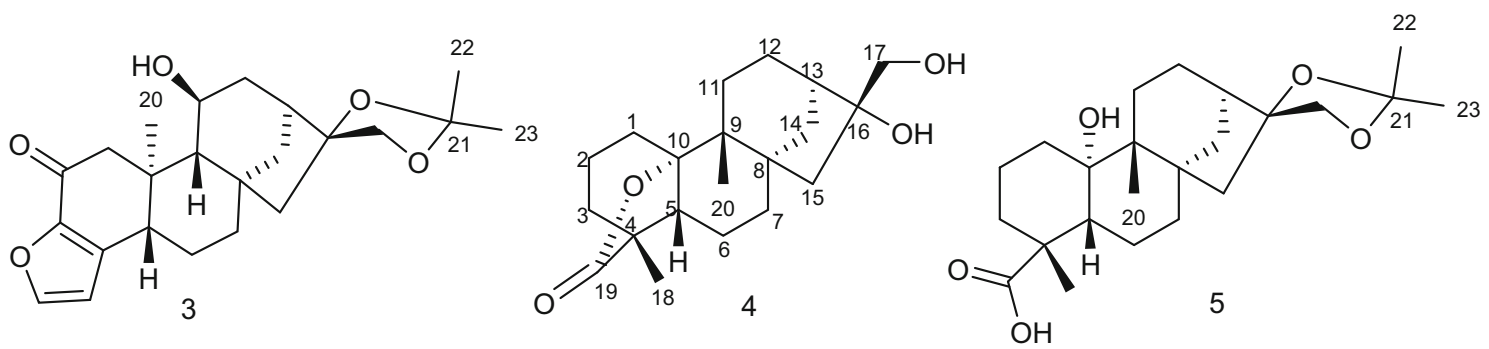<smiles>C[C@@]12CC(=O)c3occc3[C@H]1[C@@]1(C)CC[C@@]3(CO)C[C@@H]2O[C@@H]31</smiles>

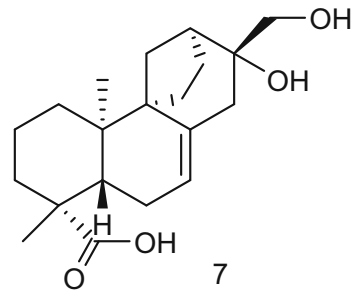

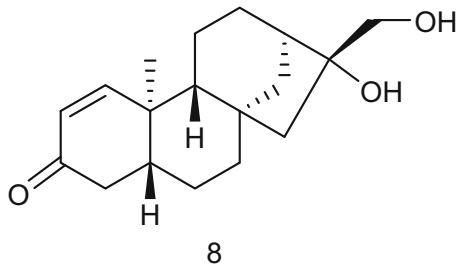

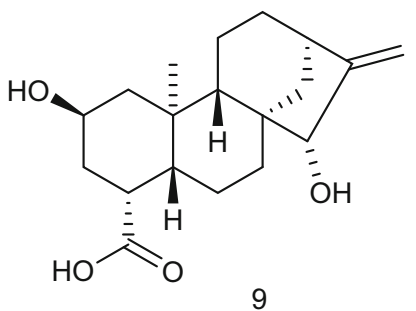

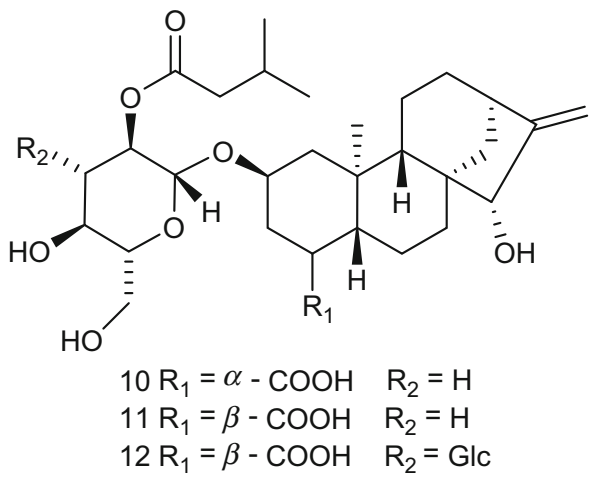

Fig. 1 Structures of compounds 1-12

coffee beans, and found nearly 90 diterpenoids [6-9]. Yunnan Arabica Coffee was the Coffea arabica which were planted in Yunnan province. Along with the planting scale expanded to 120 thousand hectares, Yunnan province became a well-known cultivation base of $C$. arabica in the world. In order to investigate the chemical constituents of Yunnan Arabica Coffee and find bioactivity diterpenoids, we took Yunnan Arabica Coffee green beans collected in Dehong as the subject, and discovered five new ent-kaurane diterpenoids, along with seven known diterpenoids (Fig. 1). Herein, the isolation, structural elucidation, and their relevant bioactivities were also described.

\section{Results and Discussion}

Mascaroside III (1) was isolated as a white amorphous powder. The molecular formula $\mathrm{C}_{36} \mathrm{H}_{44} \mathrm{O}_{13}$ was deduced from the molecular ion peak at $\mathrm{m} / \mathrm{z}[\mathrm{M}+\mathrm{Na}]^{+} 707.2670$ (calcd for $\mathrm{C}_{36} \mathrm{H}_{44} \mathrm{O}_{13} \mathrm{Na}$, 707.2674) in HREIMS. The IR spectrum indicated that 1 possessed hydroxyl $\left(3440 \mathrm{~cm}^{-1}\right)$ and $\alpha, \beta$ unsaturated ketone $\left(1650 \mathrm{~cm}^{-1}\right)$ groups. The ${ }^{13} \mathrm{C}$ NMR (DEPT) data (Tables 2, 3) showed 36 carbon resonances, attributed to a monosaccharide, a cinnamic acids group and an aglycone moiety, and the aglycone moiety were classified as one methyl $\left(\delta_{\mathrm{C}}\right.$ 15.7), 7 methylenes (including one 
Table $1{ }^{1} \mathrm{H}$ NMR spectral data of compounds $\mathbf{1}-\mathbf{5}[\delta$ in ppm, $J$ in $\mathrm{Hz}]$

\begin{tabular}{|c|c|c|c|c|c|}
\hline Position & $\mathbf{1}^{\mathrm{a}}$ & $2^{\mathrm{a}}$ & $3^{\mathrm{b}}$ & $4^{a}$ & $5^{\mathrm{b}}$ \\
\hline \multirow[t]{2}{*}{1} & $2.39(\mathrm{~d}, 16.3)$ & $2.42(\mathrm{~d}, 16.3)$ & $2.33(\mathrm{~d}, 16.1)$ & $1.28(\mathrm{dd}, 13.6,4.4)$ & $0.94(\mathrm{~m})$ \\
\hline & $2.74(\mathrm{~d}, 16.3)$ & $2.77(\mathrm{~d}, 16.3)$ & $2.83(\mathrm{~d}, 16.1)$ & $1.81(\mathrm{~m})$ & $2.01(\mathrm{dd}, 14.8,5.9)$ \\
\hline \multirow[t]{2}{*}{2} & - & - & - & $1.19(\mathrm{~m})$ & $1.52(\mathrm{~m})$ \\
\hline & - & - & - & $1.72(\mathrm{~m})$ & $1.64(\mathrm{~m})$ \\
\hline \multirow[t]{2}{*}{3} & - & - & - & $1.58(\mathrm{~m})$ & $1.01(\mathrm{~m})$ \\
\hline & - & - & - & $1.65(\mathrm{~m})$ & $2.10(\mathrm{~m})$ \\
\hline 5 & $2.83(\mathrm{br} \mathrm{d}, 14.2)$ & $2.85($ br d, 12.6) & $2.77(\mathrm{dd}, 12.4,2.4)$ & $1.94(\mathrm{dd}, 14.0,4.8)$ & $1.53(\mathrm{~m})$ \\
\hline \multirow[t]{2}{*}{6} & $1.61(\mathrm{~m})$ & $1.63(\mathrm{~m})$ & $1.62(\mathrm{~m})$ & $1.57(\mathrm{~m})$ & $1.84(\mathrm{~m})$ \\
\hline & $2.01(\mathrm{~m})$ & $2.03(\mathrm{~m})$ & $1.99(\mathrm{~m})$ & $1.86(\mathrm{~m})$ & $1.89(\mathrm{~m})$ \\
\hline \multirow[t]{2}{*}{7} & $1.72(\mathrm{~m})$ & $1.73(\mathrm{~m})$ & $1.78(\mathrm{~m}, 2 \mathrm{H})$ & $1.77(\mathrm{~m})$ & $1.64(\mathrm{~m})$ \\
\hline & $2.04(\mathrm{~m})$ & $2.06(\mathrm{~m})$ & & $1.90(\mathrm{~m})$ & $2.22(\mathrm{~d}, 12.1)$ \\
\hline 9 & $1.61(\mathrm{~m})$ & $1.63(\mathrm{~m})$ & $1.61(\mathrm{~m})$ & - & - \\
\hline \multirow[t]{2}{*}{11} & $3.86(\mathrm{~m})$ & $3.89(\mathrm{~m})$ & $3.93(\mathrm{~m})$ & $1.72(\mathrm{~m})$ & $1.44(\mathrm{~m})$ \\
\hline & - & - & - & $2.20(\mathrm{dd}, 13.8,5.8)$ & $1.75(\mathrm{~m})$ \\
\hline \multirow[t]{2}{*}{12} & $1.72(\mathrm{~m})$ & $1.73(\mathrm{~m})$ & $1.81(\mathrm{~m})$ & $1.61(\mathrm{~m})$ & $1.45(\mathrm{~m})$ \\
\hline & $1.78(\mathrm{~m})$ & $1.78(\mathrm{~m})$ & $1.95(\mathrm{~m})$ & $1.63(\mathrm{~m})$ & $1.51(\mathrm{~m})$ \\
\hline 13 & $2.10(\mathrm{~m})$ & $2.13(\mathrm{~m})$ & $2.15(\mathrm{~m})$ & $1.90(\mathrm{~m})$ & $2.11(\mathrm{~m})$ \\
\hline \multirow[t]{2}{*}{14} & $1.74(\mathrm{~m})$ & $1.73(\mathrm{~m})$ & $1.57(\mathrm{~m})$ & $1.77(\mathrm{~m})$ & $1.50(\mathrm{~m})$ \\
\hline & $1.77(\mathrm{~m})$ & $1.76(\mathrm{~m})$ & $1.85(\mathrm{~m})$ & $1.91(\mathrm{~m})$ & $1.65(\mathrm{~m})$ \\
\hline \multirow[t]{2}{*}{15} & $1.37(\mathrm{~d}, 14.3)$ & $1.40(\mathrm{~d}, 14.4)$ & $1.85(\mathrm{~m})$ & $1.39(\mathrm{~d}, 14.7)$ & $1.53(\mathrm{~m})$ \\
\hline & $2.12(\mathrm{~m})$ & $2.15(\mathrm{~d}, 14.4)$ & $2.40(\mathrm{~m})$ & $2.02(\mathrm{~d}, 14.7)$ & $2.44(\mathrm{~d}, 15.0)$ \\
\hline \multirow[t]{2}{*}{17} & $3.59(\mathrm{~d}, 10.2)$ & $3.53(\mathrm{~d}, 10.2)$ & $4.10(\mathrm{~d}, 9.3)$ & $3.64(\mathrm{~d}, 11.5)$ & $3.89(\mathrm{~d}, 8.6)$ \\
\hline & $4.71(\mathrm{~d}, 10.2)$ & $4.74(\mathrm{~d}, 10.2)$ & $4.27(\mathrm{~d}, 9.3)$ & $3.70(\mathrm{~d}, 11.5)$ & $4.04(\mathrm{~d}, 8.6)$ \\
\hline 18 & $6.58(\mathrm{~s})$ & $6.61(\mathrm{~s})$ & $6.42(\mathrm{~d}, 1.4)$ & $1.06(\mathrm{~s})$ & $1.23(\mathrm{~s})$ \\
\hline 19 & $7.78(\mathrm{~s})$ & $7.81(\mathrm{~s})$ & $7.60(\mathrm{~d}, 1.4)$ & - & - \\
\hline 20 & $0.78(\mathrm{~s})$ & $0.81(\mathrm{~s})$ & $0.87(\mathrm{~s})$ & $1.16(\mathrm{~s})$ & $1.08(\mathrm{~s})$ \\
\hline 22 & - & - & $1.37(\mathrm{~s})$ & - & $1.39(\mathrm{~s})$ \\
\hline 23 & - & - & $1.36(\mathrm{~s})$ & - & $1.36(\mathrm{~s})$ \\
\hline
\end{tabular}

${ }^{\text {a }}$ Data were measured at $600 \mathrm{MHz}$ in $\mathrm{CD}_{3} \mathrm{OD}$

b Data were measured at $600 \mathrm{MHz}$ in $\mathrm{CDCl}_{3}$

oxygenated), 6 methines (including one oxygenated, two olefinic), and 6 quaternary carbons (including one oxygenated, two olefinic, and one carbonyl). These data (Tables 1,2,3) were similar to those of mascaroside I [10,11] except for 10 additional signals for a cinnamic acids group. The coupling constant $\left(J_{2^{\prime \prime}}, 3^{\prime \prime}=15.9 \mathrm{~Hz}\right)$ suggested the double bond of the cinnamic acid group was trans. Besides, $\delta_{\mathrm{H}}$ $6.80(\mathrm{~d}, J=8.2 \mathrm{~Hz}), 7.10(\mathrm{~d}, J=8.2 \mathrm{~Hz})$ were due to orthoaromatic hydrogen suggested the two oxygenated $s p^{2}$ quaternary carbons were at $\mathrm{C}-6^{\prime \prime}$ and $\mathrm{C}-7^{\prime \prime}$, along with $\mathrm{CH}_{3}-10^{\prime \prime}$ linked to $\mathrm{OH}-7^{\prime \prime}$ confirmed by the HMBC correlations from $\mathrm{H}_{3}-10^{\prime \prime}\left(\delta_{\mathrm{H}} 3.88\right)$ to $\mathrm{C}-7^{\prime \prime}$. Further, the $\mathrm{OH}-6^{\prime}$ in the glucose and $\mathrm{COOH}-1^{\prime \prime}$ in trans-cinnamic acids group formed into ester were confirmed by HMBC correlations of $\mathrm{H}-6^{\prime}\left(\delta_{\mathrm{H}} 4.29,4.69\right)$ to $\mathrm{C}-1^{\prime \prime}\left(\delta_{\mathrm{C}} 169.5\right)$. The relative configuration of glucose anomeric proton was confirmed as $\beta$ on the basis of the coupling constant $\left(J_{1^{\prime}, 2^{\prime}}=7.8 \mathrm{~Hz}\right)$. Furthermore, the glucose was identified as D-form by GC analysis comparing with a standard after acid hydrolysis $[12,13]$. The relative configuration of $\mathbf{1}$ was same with mascaroside I by comparison of the NMR data. Furthermore, owing to the greatly predominant occurrence of this enantiomeric form in nature world, and until now, all the kaurene skeleton diterpenoids have been isolated from Coffea arabica were ent-kaurene series. Therefore, compound $\mathbf{1}$ was confirmed as an ent-kauranoid with the negative specific rotation value $(-126.67)$ confirmed it further. ent-Kauranoid with the configuration of C-20 being $\alpha$-orientated and H-5, H-9 being $\beta$-orientated. The key ROESY correlations of $\mathrm{H}-11\left(\delta_{\mathrm{H}} 3.86\right) / \mathrm{H}-20\left(\delta_{\mathrm{H}} 0.78\right)$, and $\mathrm{H}-5\left(\delta_{\mathrm{H}} 2.83\right) / \mathrm{H}-9\left(\delta_{\mathrm{H}} 1.61\right), \mathrm{H}-9 / \mathrm{H}-15 \mathrm{~b}\left(\delta_{\mathrm{H}} 2.12\right)$, and $\mathrm{H}-15 \mathrm{~b} /$ $\mathrm{H}_{2}-17\left(\delta_{\mathrm{H}} 3.59,4.71\right)$ allowed to assign $\mathrm{H}-11$ as $\alpha$-orientated, and $\mathrm{CH}_{2} \mathrm{OH}-17$ as $\beta$-orientated, separately [14]. Hence, the structure of $\mathbf{1}$ was determined and named as mascaroside III (Fig. 2).

Mascaroside IV (2) had the molecular formula of $\mathrm{C}_{37} \mathrm{H}_{46} \mathrm{O}_{14}$ according to the HRESIMS analysis at $\mathrm{m} / \mathrm{z}$ 
Table $2{ }^{13} \mathrm{C}$ NMR spectral data of compounds $\mathbf{1}-\mathbf{5}[\delta$ in ppm]

\begin{tabular}{|c|c|c|c|c|c|}
\hline Position & $\mathbf{1}^{\mathrm{a}}$ & $2^{a}$ & $3^{\mathrm{b}}$ & $4^{a}$ & $5^{b}$ \\
\hline 1 & $54.3(\mathrm{t})$ & $54.3(\mathrm{t})$ & $53.4(\mathrm{t})$ & $31.8(\mathrm{t})$ & $29.7(\mathrm{t})$ \\
\hline 2 & $187.7(\mathrm{~s})$ & $187.6(\mathrm{~s})$ & $185.2(\mathrm{~s})$ & $19.8(\mathrm{t})$ & $28.1(\mathrm{t})$ \\
\hline 3 & $148.0(\mathrm{~s})$ & $147.9(\mathrm{~s})$ & $146.6(\mathrm{~s})$ & $35.8(\mathrm{t})$ & $37.6(t)$ \\
\hline 4 & $144.8(\mathrm{~s})$ & $144.8(\mathrm{~s})$ & $142.1(\mathrm{~s})$ & $50.1(\mathrm{~s})$ & $49.5(\mathrm{~s})$ \\
\hline 5 & $45.8(\mathrm{~d})$ & $45.8(\mathrm{~d})$ & 44.8 (d) & $52.2(\mathrm{~d})$ & 50.1 (d) \\
\hline 6 & $23.4(\mathrm{t})$ & $23.3(\mathrm{t})$ & $22.4(\mathrm{t})$ & $21.6(\mathrm{t})$ & $21.8(\mathrm{t})$ \\
\hline 7 & $37.1(\mathrm{t})$ & $37.0(\mathrm{t})$ & $39.6(\mathrm{t})$ & $41.4(\mathrm{t})$ & $39.3(\mathrm{t})$ \\
\hline 8 & $45.2(\mathrm{~s})$ & $45.2(\mathrm{~s})$ & $42.3(\mathrm{~s})$ & $43.5(\mathrm{~s})$ & $43.8(\mathrm{~s})$ \\
\hline 9 & $62.1(\mathrm{~d})$ & $62.1(\mathrm{~d})$ & $61.0(\mathrm{~d})$ & $45.9(\mathrm{~s})$ & $43.8(\mathrm{~s})$ \\
\hline 10 & $43.8(\mathrm{~s})$ & $43.8(\mathrm{~s})$ & $43.9(\mathrm{~s})$ & $90.6(\mathrm{~s})$ & $77.1(\mathrm{~s})$ \\
\hline 11 & $66.1(\mathrm{~d})$ & $66.1(\mathrm{~d})$ & $65.2(\mathrm{~d})$ & $34.4(\mathrm{t})$ & $36.2(\mathrm{t})$ \\
\hline 12 & $37.5(\mathrm{t})$ & $37.5(\mathrm{t})$ & $36.7(\mathrm{t})$ & $24.9(\mathrm{t})$ & $19.0(\mathrm{t})$ \\
\hline 13 & $46.5(d)$ & $46.5(d)$ & 44.7 (d) & $44.8(\mathrm{~d})$ & 44.2 (d) \\
\hline 14 & $41.3(\mathrm{t})$ & $41.2(\mathrm{t})$ & $38.0(\mathrm{t})$ & $33.5(\mathrm{t})$ & $32.3(\mathrm{t})$ \\
\hline 15 & $52.0(\mathrm{t})$ & $52.0(\mathrm{t})$ & $55.1(\mathrm{t})$ & $50.9(\mathrm{t})$ & $50.2(\mathrm{t})$ \\
\hline 16 & 82.4 (s) & $82.3(\mathrm{~s})$ & 89.3 (s) & 84.9 (s) & $89.2(\mathrm{~s})$ \\
\hline 17 & $75.4(\mathrm{t})$ & $75.4(\mathrm{t})$ & $70.5(\mathrm{t})$ & $66.2(\mathrm{t})$ & $69.7(\mathrm{t})$ \\
\hline 18 & $111.4(\mathrm{~d})$ & 111.4 (d) & $110.0(\mathrm{~d})$ & $17.5(q)$ & 29.1 (q) \\
\hline 19 & $150.4(\mathrm{~d})$ & 150.4 (d) & $148.2(\mathrm{~d})$ & $183.0(\mathrm{~s})$ & $183.2(\mathrm{~s})$ \\
\hline 20 & $15.7(q)$ & $15.7(q)$ & $15.3(q)$ & $19.3(\mathrm{q})$ & $17.5(\mathrm{q})$ \\
\hline 21 & - & - & $108.1(\mathrm{~s})$ & - & $104.2(\mathrm{~s})$ \\
\hline 22 & - & - & $26.8(q)$ & - & 26.9 (q) \\
\hline 23 & - & - & $26.6(q)$ & - & $26.8(q)$ \\
\hline
\end{tabular}

${ }^{\text {a }}$ Data were measured at $150 \mathrm{MHz}$ in $\mathrm{CD}_{3} \mathrm{OD}$

b Data were measured at $150 \mathrm{MHz}$ in $\mathrm{CDCl}_{3}$

$[\mathrm{M}+\mathrm{Na}]^{+} 737.2786$ (calcd for $\mathrm{C}_{37} \mathrm{H}_{46} \mathrm{O}_{14} \mathrm{Na}, 737.2780$ ). The 1D NMR data (Tables 1,2,3) of $\mathbf{2}$ was identical to that of $\mathbf{1}$, except that the cinnamic acids group in $\mathbf{2}$ was substituted by one more oxygenated methyl, which was further verified by the $\mathrm{HMBC}$ correlations from $\mathrm{H}-10^{\prime \prime}$, and $\mathrm{H}-11^{\prime \prime}\left(\delta_{\mathrm{H}} 3.89\right)$ to $\mathrm{C}-6^{\prime \prime}$, and $\mathrm{C}-8^{\prime \prime}\left(\delta_{\mathrm{C}} 149.5\right)$. The chiral centers of $\mathbf{2}$ were same with those of compound $\mathbf{1}$. Therefore, the structure of $\mathbf{2}$ was elucidated as shown and given the name mascaroside IV.

Mascaroside V (3) was isolated as white powder. The HRESIMS of 3 showed an ion peak at $\mathrm{m} / \mathrm{z}[\mathrm{M}+\mathrm{Na}]^{+}$ 409.1987 (calcd for 409.1985) suggesting a molecular formula $\mathrm{C}_{23} \mathrm{H}_{30} \mathrm{O}_{5}$. The 1D NMR spectroscopic features showed it similar to the aglycone moiety of $\mathbf{1}$ with the differences being that three more carbon atoms $\left(\delta_{\mathrm{C}} 108.1 \mathrm{~s}\right.$, 26.8 q, 26.6 q). HSQC together with HMBC spectral signals, showed that $\mathrm{CH}_{3}-22\left(\delta_{\mathrm{C}} 26.8\right), \mathrm{CH}_{3}-23\left(\delta_{\mathrm{C}} 26.6\right)$ were located at the same $s p^{3}$ quaternary carbon (C-21 $\delta_{\mathrm{C}}$ $108.1 \mathrm{~s})$ which was confirmed by correlations from $\mathrm{H}-22, \mathrm{H}-23$ to $\mathrm{C}-21$. This three carbons group was substituted at $16-\mathrm{OH}, 17-\mathrm{OH}$ to form a ketal ring [15] based on HMBC correlations from $\mathrm{H}_{2}-17 \quad\left(\delta_{\mathrm{H}} 4.10,4.27\right)$ to
Table $3{ }^{1} \mathrm{H}$ NMR and ${ }^{13} \mathrm{C}$ NMR of the glucose and cinnamic acids group [ $\delta$ in ppm, $J$ in $\mathrm{Hz}$ ]

\begin{tabular}{|c|c|c|c|c|}
\hline & ${ }^{1} \mathrm{H}$ NMR & & ${ }^{13} \mathrm{C}$ NMR & \\
\hline & 1 & 2 & 1 & 2 \\
\hline $1^{\prime}$ & $4.32(\mathrm{~d}, 7.8)$ & $4.34(\mathrm{~d}, 7.5)$ & $104.8(\mathrm{~d})$ & 104.8 (d) \\
\hline $2^{\prime}$ & $3.22(\mathrm{~m})$ & $3.26(\mathrm{t}, 8.3)$ & $75.4(\mathrm{~d})$ & 75.4 (d) \\
\hline $3^{\prime}$ & $3.40(\mathrm{~m})$ & $3.43(\mathrm{~m})$ & $77.6(d)$ & 77.6 (d) \\
\hline $4^{\prime}$ & $3.40(\mathrm{~m})$ & $3.43(\mathrm{~m})$ & $71.5(\mathrm{~d})$ & 71.5 (d) \\
\hline $5^{\prime}$ & $3.50(\mathrm{~m})$ & $3.61(\mathrm{~d}, 10.1)$ & 75.5 (d) & 75.5 (d) \\
\hline $6^{\prime}$ & $4.29(\mathrm{~m})$ & $4.32(\mathrm{~d}, 4.7)$ & $63.9(\mathrm{t})$ & $63.8(\mathrm{t})$ \\
\hline & $4.69(\mathrm{~m})$ & $4.73(\mathrm{~m})$ & - & - \\
\hline $1^{\prime \prime}$ & - & - & $169.5(\mathrm{~s})$ & $169.5(\mathrm{~s})$ \\
\hline $2^{\prime \prime}$ & $6.42(\mathrm{~d}, 15.9)$ & $6.49(\mathrm{~d}, 15.9)$ & $115.2(\mathrm{~d})$ & $115.7(d)$ \\
\hline $3^{\prime \prime}$ & $7.65(\mathrm{~d}, 15.9)$ & $7.67(\mathrm{~d}, 15.9)$ & $147.4(\mathrm{~d})$ & $147.6(d)$ \\
\hline $4^{\prime \prime}$ & - & - & $127.6(\mathrm{~s})$ & $126.9(\mathrm{~s})$ \\
\hline $5^{\prime \prime}$ & $7.20(\mathrm{~s})$ & $6.95(\mathrm{~s})$ & $111.8(\mathrm{~d})$ & $107.0(\mathrm{~d})$ \\
\hline $6^{\prime \prime}$ & - & - & $150.8(\mathrm{~s})$ & $149.5(\mathrm{~s})$ \\
\hline $7^{\prime \prime}$ & - & - & $149.4(\mathrm{~s})$ & $139.8(\mathrm{~s})$ \\
\hline $8^{\prime \prime}$ & $6.80(\mathrm{~d}, 8.2)$ & - & $116.5(\mathrm{~d})$ & $149.5(\mathrm{~s})$ \\
\hline $9^{\prime \prime}$ & $7.10(\mathrm{~d}, 8.2)$ & $6.95(\mathrm{~s})$ & $124.3(\mathrm{~d})$ & $107.0(\mathrm{~d})$ \\
\hline $10^{\prime \prime}$ & $3.88(\mathrm{~s})$ & $3.89(\mathrm{~s})$ & $56.5(q)$ & $56.9(q)$ \\
\hline $11^{\prime \prime}$ & - & $3.89(\mathrm{~s})$ & - & $56.9(q)$ \\
\hline
\end{tabular}

$\delta_{\mathrm{H}}$ Data were measured at $600 \mathrm{MHz}$ in $\mathrm{CD}_{3} \mathrm{OD}$

$\delta_{\mathrm{C}}$ Data were measured at $150 \mathrm{MHz}$ in $\mathrm{CD}_{3} \mathrm{OD}$

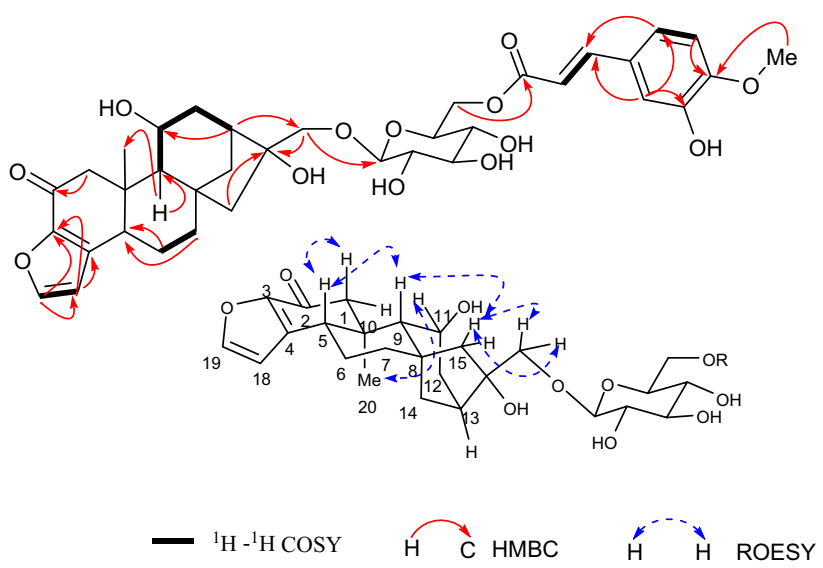

Fig. 2 Key correlations in 2D NMR spectra of compound $\mathbf{1}$

C-21.The ROESY correlations were similar to compound $\mathbf{1}$, consequently, the structure of $\mathbf{3}$ was confirmed as mascaroside $\mathrm{V}$.

20-nor-cofaryloside I (4) a white amorphous powder, displayed a $[\mathrm{M}+\mathrm{Na}]^{+} 357.2032$ (calcd for 357.2036) in HREIMS, consistent with the molecular formula of $\mathrm{C}_{20} \mathrm{H}_{30} \mathrm{O}_{4}$, indicating 6 degrees of unsaturation. The compound 4 displayed similar characteristic signals to $10 \alpha, 16 \alpha, 17$-trihydroxy-9 $\alpha$-methyl-15-oxo-20-nor-kauran- 

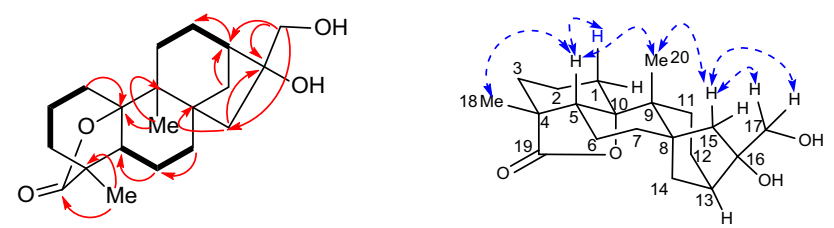

${ }^{1} \mathrm{H}-{ }^{1} \mathrm{H}$ COSY
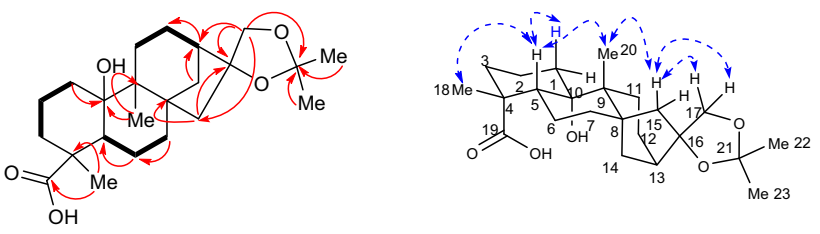

- ${ }^{1} \mathrm{H}-{ }^{1} \mathrm{H} \operatorname{COSY}$

H C̀ HMBC

H

Fig. 4 Key correlations in 2D NMR spectra of compound 5

Fig. 3 Key correlations in 2D NMR spectra of compound 4

19-oic acid $\gamma$-lactone (A) $[16,17]$ except for the absence of the carbonyl groups at $\mathrm{C}-15$. This was confirmed by the chemical shift at C-15 ( $\left.\delta_{\mathrm{C}} 50.9\right)$ in 4 which was upfield shifted comparing to that in $\mathrm{A}\left(\delta_{\mathrm{C}} 224.0\right)$. Besides, the $\mathrm{HMBC}$ correlations from $\mathrm{H}_{2}-15\left(\delta_{\mathrm{H}} 1.39,2.02\right)$ to $\mathrm{C}-16\left(\delta_{\mathrm{C}}\right.$ 84.9) and $\mathrm{C} 8\left(\delta_{\mathrm{C}} 43.5\right)$ also supported these change. On biogenetic grounds, compound $\mathbf{4}$ as an ent-kaurane with the configuration of $\mathrm{H}-5$ and $\mathrm{H}-9$ being $\beta$-orientated, while $\mathrm{OH}-10$ being $\alpha$-orientated. Its ROESY correlations showed cross peaks of $\mathrm{H}-5\left(\delta_{\mathrm{H}} 1.94\right) / \mathrm{Me}-18\left(\delta_{\mathrm{H}} 1.06\right), \mathrm{H}-5 / \mathrm{Me}-20$ $\left(\delta_{\mathrm{H}} 1.16\right), \mathrm{Me}-20 / \mathrm{H}-15 \mathrm{~b}\left(\delta_{\mathrm{H}} 2.02\right), \mathrm{H}-15 \mathrm{~b} / \mathrm{H}_{2}-17\left(\delta_{\mathrm{H}} 3.64\right.$, 3.70), revealing that the orientation of C-18, C-20 and C-17 was $\beta$-orientated (Fig. 3). Thereupon, the structure of 4 was identified as $10 \alpha, 16 \alpha, 17$-trihydroxy-9 $\beta$-methyl-20-norent-kauran-19-oic acid $\gamma$-lactone, and named 20-nor-cofaryloside I.

20-nor-cofaryloside II (5) possessed the molecular formula of $\mathrm{C}_{23} \mathrm{H}_{36} \mathrm{O}_{5}$, according to the HRESIMS analysis at $\mathrm{m} / \mathrm{z}[\mathrm{M}-\mathrm{H}]^{-} 391.2488$ (calcd for 391.2490). Analyses of $5^{\prime} \mathrm{s}{ }^{1} \mathrm{H}$ and ${ }^{13} \mathrm{C}$ NMR data indicated the existence of 23 carbon resonances, and C-21 ( $\left.\delta_{\mathrm{C}} 104.2 \mathrm{~s}\right), \mathrm{C}-22\left(\delta_{\mathrm{C}} 26.9 \mathrm{q}\right)$ and $\mathrm{C}-23\left(\delta_{\mathrm{C}} 26.9 \mathrm{q}\right)$ suggesting that the structure of compound $\mathbf{5}$ had the same ketal ring as compound $\mathbf{3}$ and this deduction was further supported by HMBC correlations from $\mathrm{H}_{2}-17, \mathrm{H}_{3}-22$ and $\mathrm{H}_{3}-23$ to $\mathrm{C}-21$. The other 20 carbon signals showed that compound 5 was similar to 4 while the chemical shift of the oxygenated $s p^{3}$ quaternary carbon C-10 $\left(\delta_{\mathrm{C}} 77.1\right)$ of 5 was upfield shifted comparing to that of $\mathbf{4}\left(\delta_{\mathrm{C}}\right.$ 90.6), and the molecular weight of 5 was 18 units more than that of $\mathbf{4}$ along with the degrees of unsaturation decrease by one. Therefore, the lactone linkage which assigned between $\mathrm{COOH}-19$ and $\mathrm{OH}-10$ was ring opened in $\mathbf{5}$. The relative configuration of 5 (Fig. 4) was same with 4. Thus, the structure was defined as 10 $\alpha$-hydroxy- 16 $\alpha, 17-[(1-$ methylethylidene)bis(oxy)]-9 $\beta$-methyl-20-nor-ent-kauran-

19-oic acid, and named 20-nor- cofaryloside II.

Seven known diterpenoids were also obtained from this genus, bengalensol [18], villanovane [10], tricalysione A [14], $2 \beta, 16 \alpha, 17$-trihydroxy-ent-kauran-19 $\alpha$-oic acid [19], 2-O-(2O-isovaleryl- $\beta$ - D-gluco-pyranosyl)-4 $\alpha$-atractyligenin [20], 2-O-(2-O-isovaleryl- $\beta$-D-gluco-pyranosyl)- $4 \beta$-atrac- tyligenin [20], 3-O- $\beta$-D-glucopyranosyl-2-O-(2-O-isovaleryl- $\beta$-Dgluco-pyranosyl)-4 $\beta$-atracty ligenin [20]. Their structures were identified by comparison of their NMR data with literature data.

Compounds 1-5, 7, 8 were evaluated for cytotoxicity against HL-60, A-549, SMMC-7721, MCF-7 and SW480 cell lines. Unfortunately, they were inactive against all test cells (Electronic supplementary material, Table S1).

\section{Experimental Section}

\subsection{General Experimental Procedures}

1D and 2D NMR spectra were obtained on a Bruker Avance III $600 \mathrm{MHz}$ spectrometer (Bruker Biospin GmbH, Karlsruhe, Germany). HREIMS was measured on Waters Xevo TQ-S and Waters Autospec Premier P776 mass spectrometers (Waters, Milford, MA, USA). HRESIMS were recorded on an Agilent 6200 Q-TOF MS system (Agilent Technologies, Santa Clara, CA, USA). UV spectra were recorded on a Shimadzu UV2401PC (Shimadzu, Kyoto, Japan). Optical rotations were obtained on a JASCO P-1020 digital polarimeter (Horiba, Kyoto, Japan). IR spectra were detected on Bruker Tensor 27 FTIR (KBr pellets) spectrometers. Sephadex LH-20 (Amersham Biosciences, Upssala, Sweden) and silica gel (Qingdao Haiyang Chemical Co., Ltd) were used for column chromatography (CC). Preparative high performance liquid chromatography (prep-HPLC) was performed on an Agilent 1100 liquid chromatography system equipped with Zorbax SB-C18 columns $(9.4 \mathrm{~mm} \times 250 \mathrm{~mm})$ and a DAD detector (Agilent Technologies, Santa Clara, CA, USA). Thin-layer chromatography was performed on precoated TLC plates $(200-250 \mu \mathrm{m}$ thickness, silica gel 60 F254, Qingdao Marine Chemical, Inc.), and spots were visualized by heating after spraying.

\subsection{Plant Material}

The green coffee beans of Coffea arabica L. were harvested in December 2014 and identified by Hong-bo Zhang, Dehong Institute of Tropical Agriculture. A voucher specimen of $C$. arabica was deposited in the Herbarium of Kunming Institute of Botany, Chinese Academy of Sciences (No. KCF 201412). 


\subsection{Extraction and Isolation}

The air-dried and powdered green Dehong coffee beans $(18 \mathrm{~kg})$ were extracted with $95 \%$ methanol three times, and then the combined filtrates were concentrated under reduced pressure to give a crude extract $(5 \mathrm{~kg})$. The crude extract was suspended in $\mathrm{H}_{2} \mathrm{O}$ and extracted with petroleum ether (PE), ethyl acetate (EtOAc), respectively. The EtOAc layer (160 g) was got rid of saccharides by D101 and then subjected to RP-18 column chromatography which eluted with $\mathrm{MeOH}-\mathrm{H}_{2} \mathrm{O}$ (gradient from 15:85 to $100: 0 \mathrm{v} / \mathrm{v})$ to yield four fractions: fraction $1(20 \mathrm{~g})$, fraction $2(19 \mathrm{~g})$, fraction $3(30 \mathrm{~g})$, and fraction $4(24 \mathrm{~g})$. Fraction 4 was separated on silica gel $\mathrm{CC}$ using a $\mathrm{CHCl}_{3}-\mathrm{MeOH}$ gradient solvent system $(80: 0 \rightarrow 1: 1, \mathrm{v} / \mathrm{v})$ to obtain eight subfractions (fraction $4-1$ to 4-8). Then fraction 4-6 $(6.5 \mathrm{~g})$ was chromatographed on $\mathrm{RP}-18 \mathrm{CC}\left(\mathrm{MeOH}-\mathrm{H}_{2} \mathrm{O}\right.$ 10:90-100:0 v/v), Sephadex LH-20 (MeOH) and then purified by semipreparative HPLC (elute with $\mathrm{CH}_{3} \mathrm{CN}-$ $\left.\mathrm{H}_{2} \mathrm{O} 15-75 \%, 30 \mathrm{~min}\right)$ to afford $1(5 \mathrm{mg}), 2(7 \mathrm{mg}), \mathbf{1 0}$ (2 mg), 11 (8 mg), 12 (40 mg). In the same way, $\mathbf{5}$ (14 mg), 6 (4 mg), 7 (17 mg) were isolated from fraction 4-2 (370 mg) and 3 (2 mg), 4 (5 mg), 8 (3 mg), 9 (6 mg) were isolated from fraction 4-3 (2.7 g).

\subsection{Mascaroside III (1)}

White amorphous powder; $[\alpha]_{\mathrm{D}}^{19}-126.67(c 0.150, \mathrm{MeOH})$; UV (MeOH) $\lambda_{\max }(\log \varepsilon) 329$ (4.87), 281 (4.14), 240 (3.94), 216 (3.97), 202 (4.05) nm; IR (KBr) $v_{\max } 3439,2923$, 2878,1703, 1657, 1515, 1437, 1270, 1165, 1126, $1033 \mathrm{~cm}^{-1}$; ${ }^{1} \mathrm{H}\left(600 \mathrm{MHz}, \mathrm{CD}_{3} \mathrm{OD}\right)$ and ${ }^{13} \mathrm{C} \mathrm{NMR}\left(150 \mathrm{MHz}, \mathrm{CD}_{3} \mathrm{OD}\right)$ data, Tables 1, 2 and 3; ESIMS $m / z 707[\mathrm{M}+\mathrm{Na}]^{+}$; HREIMS $m / z,[\mathrm{M}+\mathrm{Na}]+707.2670$ (calcd for $\mathrm{C}_{36} \mathrm{H}_{44}$ $\left.\mathrm{O}_{13} \mathrm{Na}, 707.2674\right)$.

\subsection{Mascaroside IV (2)}

White amorphous powder; $[\alpha]_{\mathrm{D}}^{19}-107.20(c 0.213, \mathrm{MeOH})$; UV (MeOH) $\lambda_{\max }(\log \varepsilon) 332$ (4.00), 279 (4.03), 241 (4.03), 202 (4.12) nm; IR (KBr) $v_{\max } 3439,2924,2855,1706,1663$, $1513,1436,1258,1155,1113,1042 \mathrm{~cm}^{-1}$; ${ }^{1} \mathrm{H}(600 \mathrm{MHz}$, $\left.\mathrm{CD}_{3} \mathrm{OD}\right)$ and ${ }^{13} \mathrm{C} \mathrm{NMR}\left(150 \mathrm{MHz}, \mathrm{CD}_{3} \mathrm{OD}\right)$ data, Tables 1 , 2, and 3; ESIMS $m / z 737[\mathrm{M}+\mathrm{Na}]^{+}$; HREIMS $m / z$ $[\mathrm{M}+\mathrm{Na}]^{+} 737.2786$ (calcd for $\mathrm{C}_{37} \mathrm{H}_{46} \mathrm{O}_{14} \mathrm{Na}, 737.2780$ ).

\subsection{Mascaroside V (3)}

White amorphous powder; $[\alpha]_{\mathrm{D}}^{19}-132.81\left(c 0.243, \mathrm{CHCl}_{3}\right)$; $\mathrm{UV}\left(\mathrm{CHCl}_{3}\right) \lambda_{\max }(\log \varepsilon) 276$ (4.05), 232 (3.71), 208 (3.67), 198 (3.64) nm; IR (KBr) $v_{\max } 3492,2925,2866,1665$, 1436, 1368, 1208, 1128, $1049 \mathrm{~cm}^{-1} ;{ }^{1} \mathrm{H} \quad(600 \mathrm{MHz}$,
$\left.\mathrm{CDCl}_{3}\right)$ and ${ }^{13} \mathrm{C}$ NMR $\left(150 \mathrm{MHz}, \mathrm{CDCl}_{3}\right)$ data, Tables 1,2; ESIMS $m / z 409[\mathrm{M}+\mathrm{Na}]^{+}$; HREIMS $m / z[\mathrm{M}+\mathrm{Na}]^{+}$ 409.1987 (calcd for $\mathrm{C}_{23} \mathrm{H}_{30} \mathrm{O}_{5} \mathrm{Na}, 409.1985$ ).

\subsection{0-Nor-cofaryloside I (4)}

white amorphous powder; $[\alpha]_{\mathrm{D}}^{19}-7.77$ ( 0 0.206, MeOH); UV (MeOH) $\lambda_{\max }(\log \varepsilon) 274$ (1.85), 206 (2.59) nm; IR $(\mathrm{KBr}) v_{\max } 3439,2931,2870,1759,1632,1443,1382$, $1174,1136,1148,935 \mathrm{~cm}^{-1} ;{ }^{1} \mathrm{H}\left(600 \mathrm{MHz}, \mathrm{CD}_{3} \mathrm{OD}\right)$ and ${ }^{13} \mathrm{C}$ NMR (150 MHz, $\mathrm{CD}_{3} \mathrm{OD}$ ) data, Tables 1,2; ESIMS $m /$ z $737[\mathrm{M}+\mathrm{Na}]^{+}$; HREIMS $m / z[\mathrm{M}+\mathrm{Na}]^{+} 357.2032$ (calcd for $\mathrm{C}_{20} \mathrm{H}_{30} \mathrm{O}_{4} \mathrm{Na}, 357.2036$ ).

\subsection{0-Nor-cofaryloside II (5)}

White amorphous powder; $[\alpha]_{\mathrm{D}}^{18}-51.01\left(c 0.105, \mathrm{CHCl}_{3}\right)$; $\mathrm{UV}\left(\mathrm{CHCl}_{3}\right) \lambda_{\max }(\log \varepsilon) 280$ (2.85), 241 (2.96), 229 (2.83), $192(1.77) \mathrm{nm}$; IR (KBr) $v_{\max } 3442,2936,2872,1718$, 1699, 1464, 1373, 1252, 1213, 1052, $970 \mathrm{~cm}^{-1} ;{ }^{1} \mathrm{H}$ NMR $\left(600 \mathrm{MHz}, \mathrm{CDCl}_{3}\right)$ and ${ }^{13} \mathrm{C} \mathrm{NMR}\left(150 \mathrm{MHz}, \mathrm{CDCl}_{3}\right)$ data, Tables 1 and 2; ESIMS $m / z 391[\mathrm{M}-\mathrm{H}]^{-}$; HREIMS $m / z$ $[\mathrm{M}-\mathrm{H}]^{-} 391.2488$ (calcd for $\mathrm{C}_{23} \mathrm{H}_{35} \mathrm{O}_{5}, 391.2490$ ).

\subsection{Cytotoxicity Assay}

The cytotoxicity against HL-60, A-549, SMMC-7721, MCF-7 and SW480 cell lines of compounds 1-5, 7, 8 were tested by using MTS method. MTS [3-(4,5-dimethylthiazol-2-yl)-5(3-carboxymethoxyphenyl)-2-(4-sulfopheny)-

$2 H$-tetrazolium] is an analogue of MTT [21], which can be reduced into soluble formazan by succinate dehydrogenase in mitochondria of living cells. Moreover, the optical density value of formazan $(490 \mathrm{~nm})$ is proportional to the number of living cells.

Acknowledgments This work was supported financially by Programme of Key New Productions of Yunnan Province, Centre of CHINA (No. 2015BB002), The STS Programme of Chinese Academy of Sciences (KFJ-SW-STS-143-8), as well as Foundation of State Key Laboratory of Phytochemistry and Plant Resources in West China (P2015-ZZ09).

\section{Compliance with Ethical Standards}

Conflict of Interest All authors declare no conflict of interest.

Open Access This article is distributed under the terms of the Creative Commons Attribution 4.0 International License (http:// creativecommons.org/licenses/by/4.0/), which permits unrestricted use, distribution, and reproduction in any medium, provided you give appropriate credit to the original author(s) and the source, provide a link to the Creative Commons license, and indicate if changes were made. 


\section{References}

1. F.F. Wei, K. Furihata, M. Koda, F.Y. Hu, T. Miyakawa, M. Tanokura, J. Agric. Food Chem. 60, 1005-1012 (2012)

2. L.R. Cagliani, G. Pellegrino, G. Giugno, R. Consonni, Talanta 106, 169-173 (2013)

3. M.M. Naidu, G. Sulochanamma, S.R. Sampathu, P. Srinivas, Food Chem. 107, 377-384 (2008)

4. W.J. Hughes, T.M. Thorpe, J. Food Sci. 52, 1078-1083 (1987)

5. I.D. Fisk, A. Kettle, S. Hofmeister, A. Virdie, J.S. Kenny, Flavor 1, 1-9 (2012)

6. X. Li, W.L. Xiao, J.X. Pu, L.L. Ban, Y.H. Shen, Z.Y. Weng, S.H. Li, H.D. Sun, Phytochemistry 67, 1336-1340 (2006)

7. K.J. Lee, J.H. Choi, H.G. Jeong, Food Chem. Toxicol. 45, 2118-2125 (2007)

8. C. Cardenas, A.R. Quesada, M.A. Medina, PLoS One 6, 1-9 (2011)

9. T. Kurzrock, K. Speer, Food Rev. Int. 17, 433-450 (2001)

10. Y. Shu, J.Q. Liu, X.R. Peng, L.S. Wan, L. Zhou, T. Zhang, M.H. Qiu, J. Agric. Food Chem. 62, 2631-2637 (2014)
11. P. Roland, G. Armin, Phytochemistry 29, 990-992 (1990)

12. J.Q. Zhao, Y.M. Wang, J.J. Lv, H.T. Zhu, D. Wang, C.R. Yang, M. Xu, Y.J. Zhang, J. Braz. Chem. Soc. 25, 1446-1454 (2014)

13. B.W. Russell, R.E. Gary, M.S. Courtney, J. Nat. Prod. 76, 1592-1597 (2013)

14. K. Nishimura, Y. Hitotsuyanagi, K. Sakakura, K. Fujita, S. Tachihara, H. Fukaya, Y. Aoyagi, T. Hasuda, T. Kinoshita, K. Takeya, Tetrahedron 63, 4558-4562 (2007)

15. R. Wang, W.H. Chen, Y.P. Shi, J. Nat. Prod. 73, 17-21 (2010)

16. A. Braca, A.I. Armenise, J. Mendez, Q. Mi, H.B. Chai, Plant Med. 70, 540-550 (2004)

17. X.F. Cai, L.I. Seon, D.N. Tien, G. Shen, K.Y. Ho, Phytother. Res. 18, 677-680 (2004)

18. M.H. Choudhury, H. Quamrul, Nat. Prod. Lett. 5, 55-60 (1994)

19. O. Emika, K. Satoshi, Phytochemistry 65, 885-890 (2004)

20. J. Liu, L. Feng, H.D. Li, Q.L. Dong, R. Chen, Helv. Chim. Acta 95, 221-226 (2012)

21. T. Mosmann, J. Immunol. Methods 65, 55-63 (1983) 